\title{
Validation of a multidisciplinary care protocol for critically ill patients with delirium
}

\author{
Validação de protocolo multiprofissional de cuidados para paciente crítico com delirium \\ Validación de protocolo multiprofesional de cuidados para paciente crítico con delirium
}

\author{
Thieli Lemos de Souza ${ }^{a}$ \\ Karina de Oliveira Azzolin ${ }^{b}$ \\ Emiliane Nogueira de Souzac
}

\section{How to cite this article:} Souza TL, Azzolin KO, Souza EN. Validation of a multidisciplinary care protocol for critically ill patients with delirium. Rev Gaúcha Enferm. 2020:41:e20190165. doi: https://doi.org/10.1590/19831447.2020.20190165
Hospital Nossa Senhora da Conceição (HNSC), Porto Alegre, Rio Grande do Sul, Brasil.

• Universidade Federal do Rio Grande do Sul (UFRGS), Escola de Enfermagem. Porto Alegre, Rio Grande do Sul, Brasil.

Universidade Federal de Ciências da Saúde de Porto Alegre (UFCSPA), Programa de Pós-Graduação em Enfermagem. Porto Alegre, Rio Grande do Sul, Brasil.

\section{ABSTRACT}

Objective: To validate a multiprofessional protocol for the care of patients with delirium admitted to an intensive care unit. Method: Methodological study with the purpose of confirming with experts the care recommendations proposed in the protocol. For the content validation process, the content validity index of $\geq 0.90$ was considered.

Results: 0 the 48 recommendations submitted to content validation, only four did not reach consensus through the content validity index. The multiprofessional protocol for patients with delirium in the intensive care unit included care related to the diagnosis of delirium, pause in sedation, early mobilization, pain management, agitation and delirium, cognitive guidance, sleep promotion, environmental interventions, and family participation.

Conclusion: The multiprofessional protocol qualifies the care provided to critically ill patients with delirium, improving clinical outcomes.

Keywords: Delirium. Critical care. Intensive care units. Patient care team.

\section{RESUMO}

Objetivo: Validar um protocolo multiprofissional para manejo de pacientes com delirium internados em unidade de terapia intensiva. Método: Estudo metodológico com finalidade de verificar junto aos juízes a recomendação dos cuidados propostos no protocolo. Para o processo de validação de conteúdo foi considerado o índice de validade de conteúdo $\geq 0,90$.

Resultados: Dos 48 cuidados submetidos à validação de conteúdo, apenas quatro não obtiveram consenso através do índice de validade de conteúdo. 0 protocolo multiprofissional para paciente em delirium na unidade de terapia intensiva englobou cuidados referentes ao diagnóstico de delirium, pausa de sedação, mobilização precoce, cuidados para dor, agitação e delirium, orientação cognitiva, promoção do sono, intervenções ambientais e participação da família.

Conclusão: Os cuidados do protocolo multiprofissional qualificam a assistência prestada ao paciente crítico em delirium, melhorando os desfechos clínicos.

Palavras-chave: Delírio. Cuidados críticos. Unidades de terapia intensiva. Equipe de assistência ao paciente.

\section{RESUMEN}

Objetivo: Validar un protocolo multiprofesional para manejo de pacientes con delirium internados en unidad de terapia intensiva. Método: Estudio metodologico con enfoque cuantitativo con el fin de verificar junto a los expertos la recomendación de los cuidados propuestos en el protocolo. Para el proceso de validación de contenido se consideró el índice de validez de contenido $\geq 0,90$

Resultados: De los 48 cuidados sometidos a la validación de contenido, sólo cuatro no obtuvieron consenso a través del índice de validez de contenido. El protocolo multiprofesional para paciente en delirium en la unidad de terapia intensiva englobó cuidados referentes al diagnóstico de delirium, pausa de sedación, movilización precoz, cuidados para dolor, agitación y delirium, orientación cognitiva, promoción del sueño, intervenciones ambientales y participación de la familia.

Conclusión: Los cuidados del protocolo multiprofesional califica la asistencia prestada al paciente crítico en delirium, mejorando los resultados clínicos.

Palabras clave: Delirio. Cuidados críticos. Unidades de cuidados intensivos. Equipo de atención al paciente. 


\section{口INTRODUCTION}

Delirium is a neurological disorder that leads to changes in consciousness and attention levels, cognitive deficits and disorientation, with an acute onset and a fluctuating course ${ }^{(1)}$. This clinical condition has a high incidence in critically ill patients, ranging from $18.9 \%$ to $68.3 \%$ in Intensive Care Units (ICU), and those submitted to mechanical ventilation may be more affected ${ }^{(1-4)}$.

Other outcomes may be associated with patients with delirium in the ICU, such as increased morbidity and mortality, length of hospital stay and mechanical ventilation, in addition to a decline in functionality ${ }^{(1,3,5)}$. Due to its fluctuating course, this dysfunction is not diagnosed or treated in a systematic or appropriate way in health services ${ }^{(4)}$.

The diagnosis of delirium is made at the bedside by a clinical examination and by any trained professional, mostly nurses, through the use of validated tools. The most commonly used tool in the ICU is the Confusion Assessment Method for the Intensive Care Unit (CAM-ICU) (2,6-7). In 2011, a multicenter study was developed to validate the CAM-ICU in Brazil, since it was already widely used in clinical practice. The results showed high specificity (96.2\%), good sensitivity (72.5\%), in addition to good predictive power when the scale is used systematically ${ }^{(6)}$. This scale can be used by nurses for the diagnosis of delirium, which is a condition associated with the Nursing Diagnosis (ND) of Acute Confusion ${ }^{(8)}$, which can be frequently found in ICUs due to the high incidence of delirium.

In clinical practice, once an accurate ND of Acute Confusion is established, the most appropriate Nursing Interventions can be carried out ${ }^{(8)}$ in order to obtain the expected results. It is in this setting that the use of care protocols is recognized as important, since, based on the best evidence, the professionals can guide the care for patients with delirium.

The relevance of this study is due to the high incidence of delirium in the ICU, which can determine a worse clinical outcome. There is still a lack of consensus regarding effective care for delirium, since pharmacological interventions are not efficient in the prevention and/or treatment of delirium ${ }^{(9)}$, while non-pharmacological and multiprofessional strategies show better results ${ }^{(10-11)}$. Therefore, this research seeks to answer the following question: What care should be part of a multiprofessional care protocol to be implemented for critically ill patients with delirium?

\section{$\square$ METHOD}

This is a methodological study consisting in the content validation of a multidisciplinary care protocol. The validation process happens in two stages ${ }^{(12)}$. In this study, the first was the elaboration of the protocol by cross-mapping the interventions proposed by the Nursing Intervention Classification $(\mathrm{NIC})^{(13)}$ for the ND of Acute Confusion, related to delirium, and which, since the current edition of NANDA-1 ${ }^{(8)}$, started to be considered a condition associated with this diagnosis, instead of a factor related with the care found from an integrative review. Thus, a correlation by similarity was established between the care for delirium from the scientific literature and the standardized language of the $\mathrm{NIC}$, standardizing and validating each recommendation of care found in order to build the protocol. It should be noted that the NIC is a taxonomic structure that can be used by health professionals ${ }^{(13)}$.

Regarding the sample, studies suggest three to 42 participants for a validation study ${ }^{(12,14-15)}$. In order to obtain consistent results, 60 professionals were invited to participate in the research. These participants were defined by the network sampling strategy, in which the initial members of the sample indicate other individuals ${ }^{(14)}$. The initial identification of these professionals was made through the Lattes Platform, considering authors with scientific publications on delirium. The professionals were selected following at least one of these inclusion criteria: having clinical experience in an adult ICU of at least two years and/or being an expert in Intensive Care. Professionals from the South and Southeast regions of Brazil were invited.

After the selection, participants were approached via email. An explanatory e-mail was sent explaining the aim of the study, methods used, and the instrument for validating the protocol. A response was considered as a positive return and, thus, confidentiality was guaranteed. The deadline for the return was 30 days and, after this period, a new contact was made in order to increase the number of participants. The type of care present in the protocol was evaluated only once by each professional. The data collection period was from August 2016 to January 2017.

The results of the assessments, initially and for the purposes of this discussion, were presented through a descriptive analysis categorized by professional categories: nurses, physical therapists, physicians and others (nutritionists, pharmacists, and psychologists). In the assessment by professional category, percentages of $\geq 70 \%$ were found to be indicative of agreement ${ }^{(12)}$.

For the validation process, the Content Validity Index (CVI) was considered, which is widely used in the health area and measures the proportion of the recommendations of the protocol elements ${ }^{(12,14-15)}$. The CVI uses the following values for the responses, adapted for this study: 1 for "I do not recommend"and 4 for "I recommend". This method is calculated 
by the sum of the items that were evaluated as "recommend" - that is, with a score of 4 - using the following formula(15).

$$
C V I=\frac{\text { number of responses classified as } 4}{\text { total number of responses }}
$$

Since this is a multidisciplinary protocol, the establishment of consensus and the consequent inclusion of a recommendation in the protocol were reached when the CVI was $\geq 0.90$

The research was developed in accordance with the guidelines and standards established by Resolution 466/12 of the National Health Council. It was sent to the Research Committee of the School of Nursing and to the Ethics and Research Committee of the Universidade Federal do Rio Grande do Sul, having been approved under protocol number 1.526.221.

\section{RESULTS}

The validation process counted on the participation of 43 professionals, 19 nurses (44.2\%), 10 doctors (23.3\%), eight physical therapists (18.6\%), two pharmacists (4.7\%), two psychologists (4.7\%), and two nutritionists (4.7\%). Most professionals were female (62.8\%), with an mean age of $34.51 \pm 4.29$ years and a mean of 7.5 years of experience in the ICU. All were post-graduates, 20 were specialists in Intensive Care (46.6\%), and 13 had master's degrees (30.2\%). Most worked in assistance (81.4\%).

For the protocol validation process, the care was organized according to the following tables, with the CVI shown in the last column. Table 1 presents a diagnosis of delirium, pain management, sedation pause and administration of antipsychotics.

Table 2 shows the care recommendations related to the cognitive orientation of critically ill patients with delirium.

Table 1 - Diagnosis, pain management, sedation pause and medications. Protocol Multiprofessional care for critically ill patients with delirium

\begin{tabular}{|c|c|c|c|c|c|}
\hline \multirow[b]{2}{*}{ Care } & \multicolumn{5}{|c|}{ Recommendation } \\
\hline & $\begin{array}{l}\text { Nurse } \\
n(\%)\end{array}$ & $\begin{array}{l}\text { Physical therapist } \\
\qquad \mathbf{n}(\%)\end{array}$ & $\begin{array}{l}\text { Physician } \\
\text { n(\%) }\end{array}$ & $\begin{array}{l}\text { Others } \\
\text { n(\%) }\end{array}$ & $\mathbf{C V I}$ \\
\hline Awaking the patient daily & 18(94.7) & $8(100)$ & $9(90.0)$ & $2(33.3)$ & 0.97 \\
\hline Pausing sedation at 6:30 am & $5(27.8)$ & $5(62.5)$ & $4(40.0)$ & $2(50.0)$ & \\
\hline Pausing sedation at 7:30 am & $13(72.2)$ & $3(37.5)$ & $6(60.0)$ & $2(50.0)$ & \\
\hline $\begin{array}{l}\text { Performing spontaneous } \\
\text { ventilation tests }\end{array}$ & $13(68.4)$ & $6(75.0)$ & $7(70.0)$ & $1(16.7)$ & 0.81 \\
\hline $\begin{array}{l}\text { Awaking the patient and performing } \\
\text { a ventilation test }\end{array}$ & $15(78.9)$ & $7(87.5)$ & $9(90.0)$ & $1(16.7)$ & 0.91 \\
\hline $\begin{array}{l}\text { Evaluating the delirium with } \\
\text { CAM-ICU }^{+}\end{array}$ & 18(94.7) & $7(87.5)$ & $8(80)$ & $4(66.7)$ & 0.97 \\
\hline Performing early mobilization & 19(100) & $8(100)$ & $10(100)$ & $6(100)$ & 1 \\
\hline Assessing pain with validated scales & $17(89.5)$ & $7(87.5)$ & $10(100)$ & $4(66.7)$ & 0.97 \\
\hline $\begin{array}{l}\text { Using opioids as the drug of choice to } \\
\text { treat pain }\end{array}$ & $9(50.0)$ & $5(62.5)$ & $7(70.0)$ & $0(0.0)$ & 0.75 \\
\hline Administrating non-opioid analgesics & 18(100) & $7(87.5)$ & $9(90.0)$ & $5(83.3)$ & 1 \\
\hline $\begin{array}{l}\text { Ensuring analgesia } \\
\text { before interventions }\end{array}$ & 19(100) & $7(87.5)$ & $10(100)$ & $5(83.3)$ & 1 \\
\hline $\begin{array}{l}\text { Limiting the use of medications } \\
\text { associated with delirium }\end{array}$ & 18(94.7) & $7(87.5)$ & $9(90.0)$ & $4(66.7)$ & 1 \\
\hline $\begin{array}{l}\text { Choosing sedations that are not a risk } \\
\text { factor for delirium }\end{array}$ & 19(100) & $8(100)$ & $8(80.0)$ & $4(66.7)$ & 1 \\
\hline Administrating haloperidol & $9(50.0)$ & $6(75.0)$ & $10(100)$ & $10(100)$ & 0.93 \\
\hline
\end{tabular}

Source: Research data.

Note: " CVI - Content Validity Index; ${ }^{+}$CAM-ICU - Confusion Assessment Method for the Intensive Care Unit 
Souza TL, Azzolin KO, Souza EN

Table 2 - Cognitive orientation. Multiprofessional care protocol for critically ill patients with delirium

\begin{tabular}{|c|c|c|c|c|c|}
\hline \multirow[b]{2}{*}{ Care } & \multicolumn{5}{|c|}{ Recommendation } \\
\hline & $\begin{array}{l}\text { Nurse } \\
n(\%)\end{array}$ & $\begin{array}{l}\text { Physical therapist } \\
\qquad n(\%)\end{array}$ & $\begin{array}{l}\text { Physician } \\
\text { n(\%) }\end{array}$ & $\begin{array}{c}\text { Others } \\
\text { n(\%) }\end{array}$ & $\mathbf{C V I}^{*}$ \\
\hline $\begin{array}{l}\text { Encouraging the staff to practice verbal / written } \\
\text { orientation whenever possible }\end{array}$ & 19(100) & $8(100)$ & 10(100) & $6(100)$ & 1 \\
\hline $\begin{array}{l}\text { Calling the patient by name when starting } \\
\text { an interaction }\end{array}$ & 19(100) & $8(100)$ & 10(100) & $6(100)$ & 1 \\
\hline $\begin{array}{l}\text { Stimulating the patient with predetermined } \\
\text { questions, established in the protocol }\end{array}$ & 16(84.2) & $6(75.0)$ & $9(90.0)$ & $5(83.3)$ & 0.92 \\
\hline $\begin{array}{l}\text { Informing the characteristics of the unit, visiting } \\
\text { hours, meals and procedures }\end{array}$ & 19(100) & $8(100)$ & 10(100) & $6(100)$ & 1 \\
\hline $\begin{array}{l}\text { Explaining any noise produced by infusion } \\
\text { pumps, alarms and / or ventilators }\end{array}$ & 19(100) & $8(100)$ & 10(100) & $5(83.3)$ & 0.97 \\
\hline $\begin{array}{l}\text { Providing information to the patient about their } \\
\text { health status, prognosis and treatments }\end{array}$ & 18(94.7) & $7(87.5)$ & $7(70)$ & $6(100)$ & 0.97 \\
\hline $\begin{array}{l}\text { Offering means of listening to music and } \\
\text { television from } 6 \text { a.m. to } 8 \text { p.m. }\end{array}$ & 18(94.7) & $8(100)$ & $10(100)$ & $5(83.3)$ & 1 \\
\hline $\begin{array}{l}\text { Providing glasses and hearing aids for personal } \\
\text { use as soon as possible }\end{array}$ & 19(100) & $8(100)$ & 10(100) & $5(83.3)$ & 1 \\
\hline
\end{tabular}

Source Research data.

Note: " CVI - Content Validity Index

Care recommendations for promoting sleep are described in Table 3.
Table 4 shows the other care recommendations in the protocol related to the environment, family participation, among others.

Table 3 - Sleep Promotion. Multiprofessional care protocol for critically ill patients with delirium

\begin{tabular}{|c|c|c|c|c|c|}
\hline \multirow[b]{2}{*}{ Care } & \multicolumn{5}{|c|}{ Recommendation } \\
\hline & $\begin{array}{l}\text { Nurse } \\
n(\%)\end{array}$ & $\begin{array}{l}\text { Physical therapist } \\
\qquad n(\%)\end{array}$ & $\begin{array}{l}\text { Physician } \\
\text { n(\%) }\end{array}$ & $\begin{array}{l}\text { Others } \\
\text { n(\%) }\end{array}$ & $\mathbf{C V I}^{*}$ \\
\hline Assessing patients for sleep maintenance & 19(100) & $7(87.5)$ & 10(100) & $4(66.7)$ & 0.97 \\
\hline a) Sleep period 12:00 a.m. to 4:00 a.m. & $5(26.3)$ & $2(25.0)$ & $1(11.1)$ & $0(0.0)$ & \\
\hline b) Sleep period 10:00 p.m. to 4:00 a.m. & $14(73.7)$ & $6(75.0)$ & $8(88.8)$ & $5(100)$ & \\
\hline $\begin{array}{l}\text { Preventing the patient from sleeping during } \\
\text { the day }\end{array}$ & 18(94.7) & $8(100)$ & $8(80.0)$ & $6(100)$ & 1 \\
\hline $\begin{array}{l}\text { Performing many care actions at once, aiding } \\
\text { uninterrupted sleep. During the night: bath } \\
\text { until } 10 \text { p.m. }\end{array}$ & 18(94.7) & $8(100)$ & $9(90)$ & $6(100)$ & 0.97 \\
\hline
\end{tabular}


Table 3 - Cont.

\begin{tabular}{|c|c|c|c|c|c|}
\hline \multirow[b]{2}{*}{ Care } & \multicolumn{5}{|c|}{ Recommendation } \\
\hline & $\begin{array}{c}\text { Nurse } \\
\text { n(\%) }\end{array}$ & $\begin{array}{l}\text { Physical therapist } \\
\qquad n(\%)\end{array}$ & $\begin{array}{l}\text { Physician } \\
\text { n(\%) }\end{array}$ & $\begin{array}{l}\text { Others } \\
n(\%)\end{array}$ & $\mathbf{C V I}$ \\
\hline $\begin{array}{l}\text { Avoiding administering medication at night - } \\
\text { rescheduling, not to interrupt sleep }\end{array}$ & $19(100)$ & $8(100)$ & $10(100)$ & $5(83.3)$ & 0.97 \\
\hline $\begin{array}{l}\text { Registering vital signs considering the central } \\
\text { monitor during sleep }\end{array}$ & 18(94.7) & $8(100)$ & $9(90.0)$ & $3(33.3)$ & 1 \\
\hline Providing ear plugs and / or eye mask for sleep & $13(68.4)$ & $6(75.0)$ & $6(60.0)$ & $2(33.3)$ & 0.90 \\
\hline Individualizing alarm signs & 18(94.4) & $8(100)$ & $10(100)$ & $5(83.3)$ & 1 \\
\hline $\begin{array}{l}\text { Checking the patient's preference regarding the } \\
\text { sleeping environment }\end{array}$ & $15(83.3)$ & $6(75.0)$ & $9(90.0)$ & $6(100)$ & 1 \\
\hline Informing the benefits of the sleep-wake cycle & $19(100)$ & $8(100)$ & 10(100) & $5(8.3)$ & 1 \\
\hline $\begin{array}{l}\text { Assessing the risk for } \mathrm{PU}^{+} \text {and the permanence } \\
\text { without change of position during sleep }\end{array}$ & $17(89.5)$ & $7(87.5)$ & $9(90.0)$ & $5(83.3)$ & 1 \\
\hline $\begin{array}{l}\text { Interrupting the sleep period if the patient's } \\
\text { presents clinical changes / instabilities }\end{array}$ & 19(100) & $7(87.5)$ & $9(90.0)$ & $4(66.7)$ & 1 \\
\hline
\end{tabular}

Source: Research data.

Note: " CVI - Content Validity Index; ${ }^{\dagger}$ PU - Pressure Ulcer

Table 4 - Environment and family. Multiprofessional care protocol for critically ill patients with delirium

\begin{tabular}{|c|c|c|c|c|c|}
\hline \multirow[b]{2}{*}{ Care } & \multicolumn{5}{|c|}{ Recommendation } \\
\hline & $\begin{array}{c}\text { Nurse } \\
n(\%)\end{array}$ & $\begin{array}{l}\text { Physical therapist } \\
\text { n(\%) }\end{array}$ & $\begin{array}{c}\text { Physician } \\
\text { n(\%) }\end{array}$ & $\begin{array}{l}\text { Others } \\
n(\%)\end{array}$ & $\mathbf{C V I}^{*}$ \\
\hline $\begin{array}{l}\text { Orientating them to use clocks } \\
\text { and calendars }\end{array}$ & 19(100) & $8(100)$ & $10(100)$ & $6(100)$ & 1 \\
\hline $\begin{array}{l}\text { Allowing family members to bring } \\
\text { items: magazines, books, etc. }\end{array}$ & $18(94.7)$ & $7(87.5)$ & $10(100)$ & $6(100)$ & 0.97 \\
\hline Reducing light at night & 19(100) & $8(100)$ & $10(100)$ & $6(100)$ & 1 \\
\hline $\begin{array}{l}\text { Orientating the professionals to avoid } \\
\text { talking around the bed }\end{array}$ & 19(100) & $8(100)$ & $10(100)$ & $6(100)$ & 1 \\
\hline Controlling noise at night & $16(84.2)$ & $6(75.0)$ & $10(100)$ & $6(100)$ & 0.97 \\
\hline Making family access more flexible & 19(100) & $7(87.5)$ & $10(100)$ & $6(100)$ & 1 \\
\hline $\begin{array}{l}\text { Promoting care management, } \\
\text { facilitating family access }\end{array}$ & 18(100) & $7(87.5)$ & $9(90.0)$ & $6(100)$ & 0.97 \\
\hline $\begin{array}{l}\text { Performing rounds in visiting hours to } \\
\text { offer orientations about delirium }\end{array}$ & 19(100) & $7(87.5)$ & $6(60.0)$ & $5(83.3)$ & 0.95 \\
\hline
\end{tabular}


Table 4 - Cont

\begin{tabular}{|c|c|c|c|c|c|}
\hline \multirow[b]{2}{*}{ Care } & \multicolumn{5}{|c|}{ Recommendation } \\
\hline & $\begin{array}{l}\text { Nurse } \\
n(\%)\end{array}$ & $\begin{array}{l}\text { Physical therapist } \\
\text { n(\%) }\end{array}$ & $\begin{array}{l}\text { Physician } \\
\text { n(\%) }\end{array}$ & $\begin{array}{l}\text { Others } \\
\text { n(\%) }\end{array}$ & $\mathbf{C V} \mathbf{I}^{*}$ \\
\hline $\begin{array}{l}\text { Encouraging family interaction with } \\
\text { the patient }\end{array}$ & $14(73.7)$ & $8(100)$ & $8(80.0)$ & $5(83.3)$ & 1 \\
\hline Developing educational materials & 18(94.7) & $7(87.5)$ & $9(90.0)$ & $6(100)$ & 0.95 \\
\hline Removing devices early & $19(100)$ & $8(100)$ & $10(100)$ & $6(100)$ & 1 \\
\hline $\begin{array}{l}\text { Performing mechanical restraints } \\
\text { using "box gloves" }\end{array}$ & $15(78.9)$ & $5(62.5)$ & $6(60.0)$ & $4(66.7)$ & 0.93 \\
\hline Not arresting bed restraint & $13(68.4)$ & $5(62.5)$ & $7(70.0)$ & $7(70.0)$ & 0.87 \\
\hline Keeping the bed rails high & 19(100) & $8(100)$ & $9(90.0)$ & $5(83.3)$ & 1 \\
\hline $\begin{array}{l}\text { Providing the patient with means of } \\
\text { calling professionals, e.g., bell or light }\end{array}$ & $19(100)$ & $7(100)$ & $9(90.0)$ & $5(100)$ & 1 \\
\hline $\begin{array}{l}\text { Providing } 90 \text { minutes of quiet time } \\
\text { twice a day }\end{array}$ & $12(63.2)$ & $5(62.5)$ & $3(30)$ & $1(16.7)$ & 0.87 \\
\hline $\begin{array}{l}\text { Identifying the bed of the patient } \\
\text { with delirium, in order to maintain } \\
\text { the protocol }\end{array}$ & 18(94.7) & $8(100)$ & $6(60.0)$ & $6(100)$ & 0.97 \\
\hline
\end{tabular}

Of the 48 care recommendations submitted to validation, only four did not reach the consensus established by the CVI $\geq 0.90$ and, therefore, were not recommended to compose the protocol (as shown in the Attachment). The non-validated recommendations were:" Performing spontaneous ventilation tests", "Using opioid as the drug of choice for the treatment of pain", "Not arresting mechanical restraints to the bed" and "Providing 90 minutes of quiet time twice a day".

\section{DISCUSSION}

When analyzing the content validity, the results obtained by calculating the $\mathrm{CVI}$ recommended most of the recommendations proposed by this study, thus totaling 44 recommendations to compose the multiprofessional care protocol. During the assessment by professional category, there were some differences in agreement, which can identify different levels of knowledge about delirium.

The diagnosis of delirium is usually made by applying the CAM-ICU by any trained professional. However, despite being a validated diagnostic tool developed 15 years ago(2,6), the adherence by the multidisciplinary team still needs to improve. The systematic evaluation of delirium by medical professionals, physical therapists and nurses in Latin America and Europe, identified in a previous study, showed that CAMICU was the most used (66.9\%) instrument, being significantly more used in Brazil compared to the other countries (83\% vs $43.5 \%, \mathrm{P}<0.001)^{(7)}$.

The aforementioned results converge with the evidence of this study in relation to the use of CAM-ICU for the diagnosis of delirium, recommending and reiterating its importance in clinical practice. However, the knowledge and use of this tool requires a better understanding of all professional categories that work in the ICU. Predominantly, CAM-ICU is used in the ICU by trained nurses and can be a tool for diagnostic reasoning.

In the current edition of NANDA-1(8), delirium is an associated condition of the ND Acute Confusion, despite being treated by a multiprofessional team. This new categorization can be contested, since the nurse has both independent actions and those shared with the multiprofessional team, both for the prevention and treatment of delirium. 
The implementation of multiprofessional care is highlighted in studies. A cohort of 70 patients demonstrated the benefits of interventions for pain, agitation and delirium by developing guidelines with a pharmaceutical professional. In a second phase, sedation pause, spontaneous ventilation tests and early mobilization were incorporated. 436 patients were followed up prospectively. The results of the first phase showed a reduction in sedoanalgesia $(P=0.001)$ and length of stay in the ICU $(P=0.01)$, while in the second phase, a reduction was observed in the length of mechanical ventilation $(P=0.03)$ and in mortality $(P=0.01)^{(16)}$. Such findings corroborate the results found in this study: care related to sedation pauses and early mobilization was recommended in order to obtain better outcomes by the assistance provided. Thus, delirium is treated with feasible, multi-professional and not pharmacological actions - associating the care of the nursing team with those of physical therapy - possibly reducing risk factors.

Another retrospective study demonstrated the benefits of incorporating care related to awakening the patient and coordinating spontaneous ventilation tests, monitoring for delirium and early mobilization.159 ICU patient records were analyzed, and it was observed that the prevalence of delirium decreased significantly (38\% vs $23 \%, \mathrm{P}=0.01$ ) and that there was a reduction in the mean number of days in delirium (3.8 to 1.72 days, $P<0.001)^{(10)}$. Thus, the established consensus is emphasized, since it seems to be effective in the management of delirium, in addition to improving other clinical outcomes.

Early mobilization was a recommendation considered relevant for the critical patient with delirium. In this context, it is worth mentioning the importance of the participation of the entire multidisciplinary team during the mobilization process, from the moment of the assessment of the patient's clinical conditions to the execution of the procedure, which becomes very complex in the context of Intensive Care. A multicenter randomized clinical study, involving 200 patients, developed an early mobilization protocol by goals: no mobilization, passive movements in the bed, standing up and walking. In the intervention group, patients had more days free of delirium compared to the control group (25 vs 22 days, $P=0.01$ ), demonstrating the efficiency of mobilization for the management of delirium ${ }^{(17)}$. This evidence supports and directs the development of care protocols, encouraging early mobilization in critically ill patients with delirium, despite some difficulties encountered in clinical practice, such as infrastructure problems and work demands. In this context, the multiprofessional team needs to be engaged to safely mobilize the patient, avoiding possible adverse events, and to be aware of the benefits and the best results for the patient.
Likewise, in order to increase the quality of care, recommendations directed at pain management, agitation and delirium ${ }^{(18)}$ were mostly approved to compose the protocol. Pain assessments using the Critical Care Pain Observation Tool scale was applied in a study with 106 intensive care nurses. The results showed that, after an educational intervention, the professionals were more favorable to use of the scale ( $22.6 \%$ vs $53.8 \%, P<0.001$ ), in addition to developing more adequate analgesic management ${ }^{(19)}$. Thus, the need to adequately assess and treat pain is important so that it does not lead to increased agitation and, possibly, delirium.

The treatment with haloperidol presented with divergences in this study, as well as in scientific literature. The literature shows no evidence to justify the routine use of antipsychotics for the management of delirium ${ }^{(0,20)}$. However, it is worth mentioning that, in a situation of acute agitation, there may be an indication for the use of this medication. The use of haloperidol was reiterated by the physicians who participated in this study, since they considered this recommendation to be relevant. This was also demonstrated in a multiprofessional survey of physicians, physical therapists and nurses, in which haloperidol was the most frequently chosen drug (65.5\%) for the control of delirium ${ }^{(7)}$. In an attempt to corroborate the recommendation of pharmacological management with haloperidol in critically ill patients with delirium, the results of a systematic review were conflicting in relation to the use of antipsychotics. The authors state that, even without strong evidence, haloperidol remains the drug of choice for the treatment of delirium ${ }^{(20)}$.

The recommendations to promote sleep, such as the one for the provision of ear protectors and eye masks, showed some divergences in the assessments by the professionals. This may be related to the different realities found in Brazilian ICUs and to the many and diverse difficulties faced in clinical practice and may even reflect the resistance to the incorporation of new care and technologies. However, there was a consensus with regard to this recommendation, meaning it was considered relevant in the multiprofessional protocol, since sleep interruption is a risk factor for the development of delirium ${ }^{(18)}$.

Regarding interventions related to cognitive orientation, all of them reached a consensus, with no doubts as to their indication. Since they are easy to implement and do not require a great deal of financial and structural involvement, they require only a trained and committed team in the development of activities. Most reorientation care is already randomly performed by health professionals in the Intensive Care environment. 
Finally, it is known whether the presence of the family in the ICU in extended visits can decrease the occurrence of delirium and the length of stay of patients ${ }^{(3,11)}$, improving clinical outcomes. The recommendation related to the presence of family members was also approved in this study, as health professionals understand the relevance of the family in qualified and humanized care.

All the professionals who are part of the multiprofessional team must make their decisions using the best evidence, carrying out their functions with clarity and precision. This can be guaranteed by multiprofessional rounds or in conversations at the bedside, listing the activities that will be developed and establishing aims for the attention. Currently, nurses have the fundamental role of managing the different practices and organizing them in a systematic care.

The treatment of delirium is still not completely understood, either by the complex pathophysiology of this neurological dysfunction, or by the conflicting results of some studies. However, the protocol developed and validated in this study can assist in the care against delirium in the ICU, since the recommendations were selected from scientific evidence, validated and recommended by professionals with expertise in critical care, which may favor the resolution of delirium and, also, contribute to the improvement of other clinical outcomes.

\section{口CONCLUSION}

This study validated a multiprofessional care protocol for critically ill patients with delirium, with only four recommendations not being approved. Considering that delirium is a multifactorial dysfunction, its care must be comprehensive, encompassing physiological and pharmacological aspects, pain, agitation, and delirium management, including the use of haloperidol; and psychological aspects, with cognitive reorganization, sleep promotion, and family participation, among others.

A limitation of this study was the composition of the sample, since the participants were not selected from all regions of the country. However, the participants fulfilled the criteria consistent with clinical expertise in the assessed subject.

The importance of this study stands out due to the imminent need to prevent and treat patients who develop delirium in the ICU, since it adds numerous complications and may worsen clinical outcomes. It is also worth mentioning the incorporation of standardized languages (NANDA-I and NIC) in a study focusing on clinical practice and multiprofessional care, thus meeting the complex demands of these patients. However, more researches related to the treatment and prevention of delirium are still needed.

\section{REFERENCES}

1. Ely EW, Margolin R, Francis J, May L, Truman B, Dittus R, et al. Evaluation of delirium in critically ill patients: validation of the Confusion Assessment Method for the Intensive Care Unit (CAM-ICU). Crit Care Med. 2001;29(7):1370-9. doi: https://doi.org/10.1097/00003246-200107000-00012

2. Wan RYY, McKenzie CA, Taylor D, Camporota L, Ostermann M. Acute kidney injury as a risk factor of hyperactive delirium: a case control study. J Crit Care. 2020;55:194-7. doi: https://doi.org/10.1016/j.jcrc.2019.10.013

3. Rosa RG, Falavigna M, Silva DB, Sganzerla D, Santos MMS, Kochhann R, et al. Effect of flexible family visitation on delirium among patients in the Intensive Care Unit: the ICU visits randomized trial. JAMA. 2019;322(3):216-28. doi: https://doi.org/10.1001/jama.2019.8766

4. Ritter SRF, Cardoso AF, LINS MMP, Zoccoli TLV, Freitas MPD, Camargos EF. Underdiagnosis of delirium in the elderly in acute care hospital settings: lessons not learned. Psychogeriatrics. 2018;18(4):268-75. doi: https://doi. org/10.1111/psyg. 12324

5. Oliveira DS, Fernandes FM, Silveira MGM, Ventura MM. Factors related to delirium and mortality in older adults with femur fracture on an orthopedic unit. Geriatr Gerontol Aging. 2019;13(2):75-9. doi: https://doi.org/10.5327/ Z2447-211520191900020

6. Gusmão-Flores DG, Salluh JIF, Dal-Pizzol F, Ritter C, Tomasi CD, Lima MASD, et al. The validity and reliability of the Portuguese versions of three tools used to diagnose delirium in critically ill patients. Clinics. 2011;66(11):1917-22. doi: https://doi.org/10.1590/S1807-59322011001100011

7. Tanaka LMS, Salluh JIF, Dal-Pizzol F, Barreto BB, Zantieff R, Tobar E, et al. Delirium in intensive care unit patients under noninvasive ventilation: a multinational survey. Rev Bras Ter Intensiva. 2015;27(4):360-8. doi: https://doi. org/10.5935/0103-507X.20150061

8. Herdman HT, Kamitsuru S, editors. NANDA International Nursing Diagnoses: definitions and classification 2018-2020.11 $11^{\text {th }}$ ed. New York: Thieme; 2018.

9. van den Boogaard M, Slooter AJC, Brüggemann RJM, Schoonhoven L, Beishuizen A, Vermeijden JW, et al. Effect of haloperidol on survival among critically ill adults with a high risk of delirium: the REDUCE randomized clinical trial. JAMA. 2018;319(7):680-90. doi: https://doi.org/10.1001/jama.2018.0160

10. Bounds RN, Kram S, Speroni KG, Brice K, Luschinski MA, Harte S, et al. Effect of $A B C D E$ bundle implementation on prevalence of delirium in intensive care unit patients. Am J Crit Care. 2016;25(6):535-44. doi: https://doi.org/10.4037/ ajcc2016209

11. Rosa RG, Tonietto TF, Silva DB, Gutierres FA, Ascoli AM, Madeira LC, et al. Effectiveness and safety of an extended ICU visitation model for delirium prevention: a before and after study. Crit Care Med. 2017;45(10):1660-7. doi: https://doi.org/10.1097/CCM.0000000000002588

12. Santos EC, Oliveira ICM, Feijão AR. Validation of a nursing care protocol for patients undergoing palliative care. Acta Paul Enferm. 2016;29(4):363-73. doi: https://doi.org/10.1590/1982-0194201600051

13. Bulechek GM, Butcher HK. Dochterman JM. Classificação das Intervenções de Enfermagem (NIC). 6. ed. Rio de Janeiro: Elsevier; 2016.

14. Machado RC, Gironés P, Souza AR, Moreira RSL, Jakitsch CBV, Branco JNR. Nursing care protocol for patients with a ventricular assist device. Rev Bras Enferm. 2017;70(2):353-9. doi: https://doi.org/10.1590/0034-7167-2016-0363

15. Polit DF, Beck CT. The content validity index: are you sure you know what's being reported? Critique and recommendations. Res Nurs Health. 2006;29(5):489-97. doi: https://doi.org/10.1002/nur.20147 
16. Louzon P, Jennings H, Ali M, Kraisinger M. Impact of pharmacist management of pain, agitation, and delirium in the intensive care unit through participation in multidisciplinary bundle rounds. Am J Health Syst Pharm. 2017;74(4):253-62. doi: https://doi.org/10.2146/ajhp150942

17. Schaller SJ, Antey M, Blobner M, Edrich T, Grabitz SD, Gradwohl-Matis I, et al. Early, goal-directed mobilisation in the surgical intensive care unit: a randomised controlled trial. Lancet. 2016;388(10052):1377-88. doi: https:// doi.org/10.1016/S0140-6736(16)31637-3

18. Barr J, Fraser GL, Puntillo K, Ely EW, Gélinas C, Dasta JF, et al. Clinical practice guidelines for the management of pain, agitation, and delirium in adult patients in the intensive care unit: executive summary. Am J Health Syst Pharm. 2013;70(1):53-8. doi: https://doi.org/10.1093/ajhp/70.1.53
19. Asadi-Noghabi AA, Gholizadeh M, Zolfaghari M, Mehran A, Sohrabi M. Nurses use of critical care pain observational tool in patients with low consciousness. Oman Med J. 2015;30(4):276-82. doi: https://doi.org/10.5001/omj.2015.55

20. Barbateskovic M, Larsen LK, Oxenbøll-Collet $M$, Jakobsen JC, Perner A, Wetterslev J. Pharmacological interventions for delirium in intensive care patients: a protocol for an overview of reviews. Syst Rev. 2016;5(1):211. doi: https://doi.org/10.1186/s13643-016-0391-5

\section{ATTACHMENT}

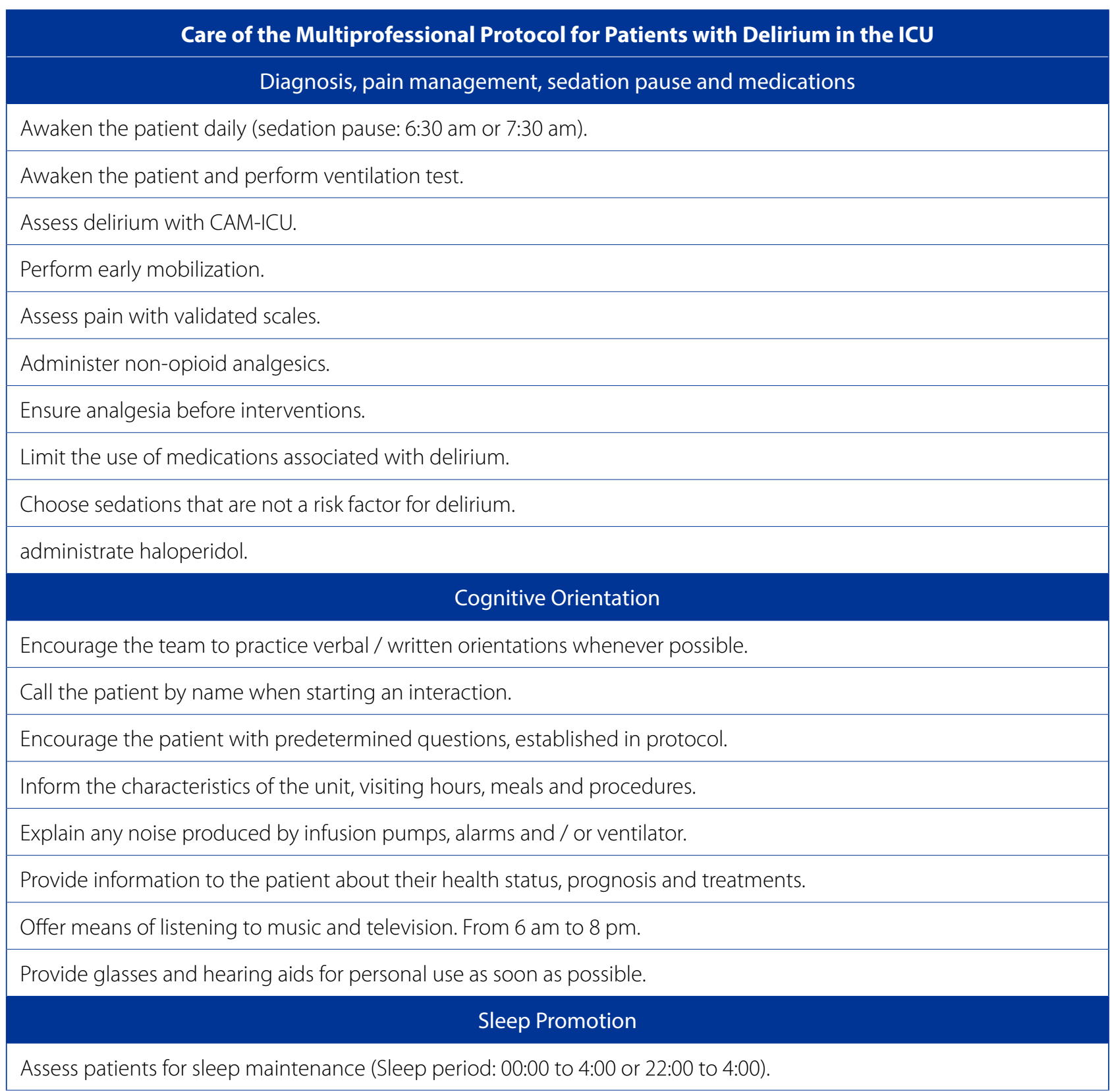


Prevent the patient from sleeping during the day.

Cluster care for uninterrupted sleep. During the night: bath until $10 \mathrm{pm}$.

Avoid administering medication at night - reschedule. Do not interrupt sleep.

Record vital signs provided by the central monitor during sleep.

Provide ear plugs and / or eye mask for sleep.

Individualize the alarm.

Check the patient's preference for the sleeping environment.

Inform the benefits of the sleep-wake cycle.

Assess the risk for PU and the permanence without changing position during sleep.

Interrupt the sleep period if the patient's clinical status changes / or if there is instabilities.

Environment and Family Participation

Orientate using clocks and calendars.

Allow family members to bring items: magazines, books, etc.

Reduce light at night.

Orientate professionals - avoid talking by the bed.

Control noise at night.

Make family access more flexible.

Promote care planning, facilitating family access.

Perform rounds in visiting hours to offer orientations about delirium.

Encourage family interaction with the patient.

Develop educational materials.

Remove devices early.

Perform "box glove" mechanical restraint.

Keep the bed rails high.

Provide the patient with a means of calling professionals, eg, bell or light.

Identify the bed of the patient who is in delirium, in order to maintain the care protocol.

\section{- Corresponding author:}

Thieli Lemos de Souza

E-mail: thielils@gmail.com

\section{Associate editor:}

Wiliam Wegner 